\title{
Modern Diffusers for Interior Design
}

Havva Demirpolat ${ }^{*}$

\begin{abstract}
In this study; the elements of the new generation ventilation systems are explained with the general design principles of the HVAC systems. Nozzles and diffusers which are the last elements of HVAC systems are explained with examples.Latest decades, air distribution elements have become the decorative elements in the interior. Air distribution elements are the last elements which complex air conditioning system. In addition to providing air and particle movement control and thermal comfort in the interior, they are also extremely important technical equipment when considering the space design. Thanks to developing design and manufacturing technologies, the latest ventilation equipment has become extremely flexible and has aesthetic appearance. Different modern diffusers are presented with a sample application project in this study. The architectural structure considered as a case study is a complex consisting of showroom, office, sales and service departments serving in the automotive sector. The planer glass facade coating system is the determining element in architecture in general, while the interior stainless steel details and mounting elements form the basic style of the sample building. In the building which is an intensive human and vehicle movement, the glass facade provides maximum natural lighting and passive heating at the same time. For the summer months, mechanical ventilation is preferred, and the $\mathrm{Cr}-\mathrm{Ni}$ ventilation equipment that
\end{abstract}

Keywords: Diffuser, nozzle, large space building, HVAC, interior design

*Assist. Prof. Dr.Faculty of Fine Arts, Selçuk University, Konya Turkey $\bigcirc$ RCID

E-mail: hdemirpolat@selcuk.edu.tr 
provides harmony with the steel structure is the most noticeable interior detail. In this article, a wide interior analysis was carried out with installation plans and sample application visuals as well as mechanical ventilation details.

\section{INTRODUCTION}

Today people spend a great majority of their time in enclosed spaces. Nowadays, architectural structures are designed to allow for many activities such as meeting, shopping, restaurant-cafe, offices, sports and health facilities and residence. In these structures, interiors that are generally used for mixed purposes are striking. In these constructions are observed with different usage purposes such as open office, mall and atriums designs. Comfort is the most important design criterion for non-standard spaces for different purposes. Thermal comfort is at the top of these criteria. The thermal conditions that people usually need for living and working are obtained by experience and these values are used in the space design. While the comfort of the environment is provided in the most appropriate way, the aesthetics of the space is another important criterion. It is very important to complete HVAC process by selecting the correct distribution elements and positioning them correctly in high cost designed structures. Thermal values in the environment, acoustic and air velocity may vary depending on the dispensing elements used. This work was devoted to the literature to provide accurate diffuser and nozzle selection in large-space building for designers.

An experimental study was performed use of nozzles in highperformance buildings by Haidong Wang et al. (Haidong,2018,347-357). A study was performed by Lun Zhang et al. on innovative cooling systems and design in large-area spaces (Lun, 2015,228-238). In this study, it was found that secondary airflow systems supported by jet diffusers are $34 \%$ more efficient. Haidong Wang et al. studied the improvement of air quality and the effect of secondary flows through the use of nozzles in longspan structures. A CFD model was designed and observed to increase the ventilation qualities of the secondary flows (Haidong, 2015,816-823). D. Int-Hout, he presented the selection criteria of vent and diffuser in HVAC systems. (Hout,2004,24-28). Bingelli C. in his study, he explained the conditions of indoor air conditioning in general and examined different applications.(Bingelli, 2003, 194-213) Patrick Sisson has also deal with the use of ventilating equipment in contemporary architecture in his work. He explained the development and shaping of modern architecture in time in parallel with the developments in air conditioning and ventilation systems. (Sisson,2017) 
In modern, high-tech buildings, sharp and measured elements of ventilation systems can be used as a design objects. Circular crosssection and rectangular cross-section air ducts could be manufactured as $\mathrm{Cr}-\mathrm{Ni}$, galvanized sheet, spiral, PVC, polyurethane, and fabric. Thanks to the sealing elements and acoustic insulation, the ducts and vents which allow designing at very low noise levels also give the identity of the buildings they design as design objects. It is also preferred that the building shell is generally flexible in high-tech constructions and that it is used in many places without hiding up the hanging elements and plenum boxes due to the steel structure. Generally, selection and material criteria of installation and ventilation equipment: mechanical calculations and parameters such as pressure losses, noise levels, airflow and blowing speeds are discussed. There has not been any study in the literature on the use of indoor diffusers and ventilation equipment as design elements.

\section{MODERN DIFFUSERS FOR HVAC SYSTEM}

In the design of HVAC system in large-space buildings, heating, cooling and supply air values are calculated primarily to provide comfort conditions suitable for the purpose of use of the building considering factors such as the number of people, lighting, computer and electronic device condition, wind, shadow and sunshine effect and architectural constraints. Account and design are made based on the pressure loss in duct, vent flow rate values together with the appropriate cross-sectional duct. Finally, diffuser selection is made for the HVAC system. In past decades when passive ventilation systems have not been enough galvanized rectangular ventilation ducts hidden in plaster ceilings and/or walls and square honeycombs and culverts mounted on gypsum surface are designed. The use of linear vent, damper vent, and square honeycombs is increasingly reduced due to the lack of aesthetic and proper ventilation conditions in new generation buildings. Slot diffusers, jet nozzles, are preferred in the interior due to their thin display. Because of the sound levels are low even at high speeds, concerts and meeting rooms are quite suitable for low sound levels such as conference rooms.

Slot diffusers; They are preferred by architects with their elegant appearance and they are widely used in air conditioning systems due to the fact that they offer homogeneous air diffusion at the same time. The ability to change the blowing directions up to 180 ${ }^{\circ}$ or to close some types when necessary gives the slot diffusers flexibility in use and installation in the field of application.

Standard slot diffusers are used for heating and cooling up to 3.0$3.5 \mathrm{~m}$ in air conditioning systems, and only for cooling purposes in 
4-5m heights. Particularly in large zones, when used for heating purposes at ceiling heights above $3.5 \mathrm{~m}$, difficulty could arise when lowering the hot air. The application height could be reached up to $6-10 \mathrm{~m}$ with variable air flow slot diffusers. Generally slot diffuser is prefered for variable ventilation air-conditioning systems (VAV) in case of $20 \%$ of the air amount falling. Otherwise, unwanted currents (reverse air movement) may occur with the cause of the air fall when the minimum trip is approached and this may cause discomfort. Slot diffusers are used almost everywhere where fixed-bed and variable air-conditioning ventilation systems are applied. These can be classified as business centers, restaurants, hotels, shops, banks, residences, hospitals, schools, trains, yachts.

Linear slot diffusers allows continuous application with $90^{\circ}$ and 135 (Figure 1) corner slots and curved slots. Width values are in the range of $3 \mathrm{~cm}-30 \mathrm{~cm}$ and the number of slots according to the air blowing from a unit length in these types are able to go up to 8 slots per slot. Painted slot diffusers are very flexible interior design solutions. Plenum box is manufactured by made of $0.6 \mathrm{~mm}$ galvanized sheet metal with diffusers. However, it is possible to use different interconnection elements to provide mounting flexibility in different projects. The most common of these are flexible connectors which offer a very flexible connection.

Figure 1. Slot Diffuser Linear and Corner Piece

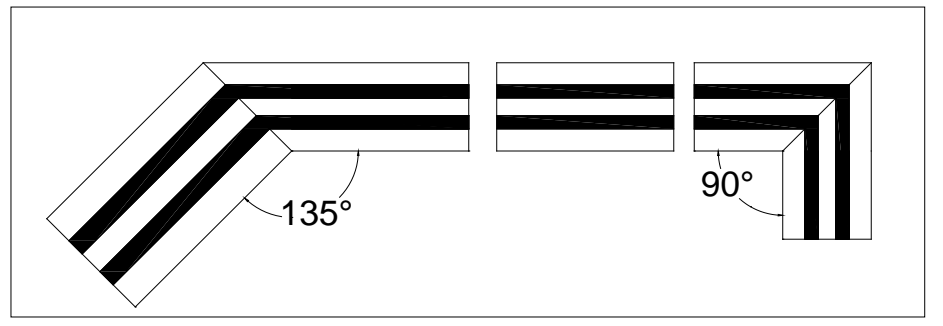

The use of slotted diffusers directly on the duct face is increasing in high-tech and industrial style building, especially in Europe and the world. In this application, circular or semi circular shaped slot diffusers are used which are mounted on the duct without any intermediate connection element. The flow rate can be set automatically and it is possible to provide different thermal comfort conditions in the interior used for different purposes with a preferred module in variable flow systems. Room thermal condition is kept under constant control via state thermostat. Remote Controllers (Remote adjuster) with set values can also be changed based on ambient climatic conditions. It is necessary to adjust the direction and velocity of the air depending on the difference between blown air temperature and ambient temperature in order to catch long range $(6-10 \mathrm{~m})$ in highstructures and to provide a homogeneous distribution. As the air 
circulation speed increases, comfort are reduced, noise level increases. As it is shown in (Figure 2) the air circulation speed increases sensible temperature is reduced with nearly 8 times.

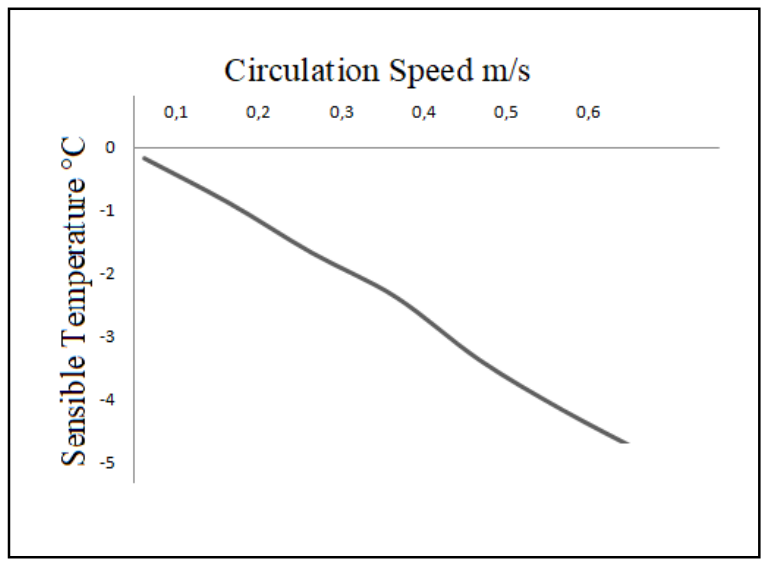

Swirl diffusers, as it seen (Figure 3), have a wide temperature range $\left(-30^{\circ} \mathrm{C}, 100^{\circ} \mathrm{C}\right)$ and are preferred for use in high $(12-15$ $\mathrm{m})$ constructions. It makes suitable for using in systems variable flow and constant flow with turbulent blowing and high inductions. The direction of the air beam can change direction according to the heating and cooling condition by a moving mechanism. The blowing air can move in the direction parallel to the ceiling in the case of cooling whereas it can move downward in the event of heating. Generally, the direction of the blowing angle can be changed by a servo motor or if it is necessary economical manually. It is convenient the use of in combination with different colors and lighting elements

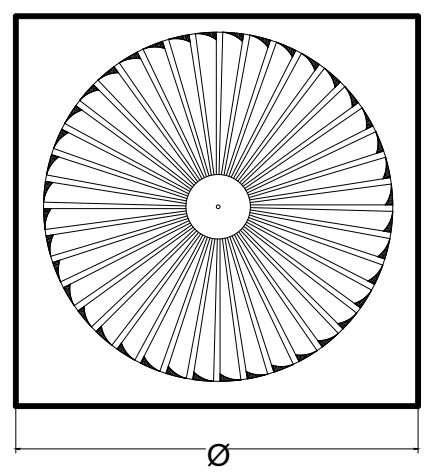

Figure 2. Variation of Sensible Temperature with Air Circulation Speed

Figure 3. Swirl Diffuser 


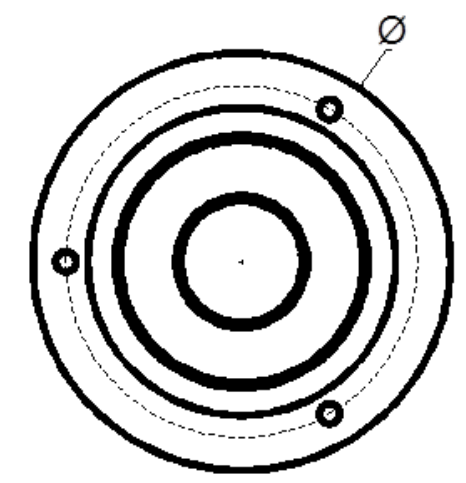

Hot air raises top of building whereas the cold air falls down. For this reason, blowing speeds are particularly sensitive to cooling loads. It is stabilized by the ambient air and reaches to the floor surface at a value close to the limit values. Therefore the use of nozzles is becoming increasingly widespread. Especially diffusers are placed on the side walls to obtain a modern and aesthetic appearance in the high office buildings, large space and high structures. So the most effective ventilation angle can be captured. In the jet outlet, the openness can be set to rise somewhat horizontally and the temperature rising from humans and other heat sources can be mixed to provide a homogeneous distribution in the environment. Especially in cooling periods, the jet diffuser can be directed upwards so that cold air blown in summer is not directly directed to humans and distribution is better. In winter, the orientation is made downwards so that the hot air that is blown can be distributed more inferiorly. Jet nozzles, as it seen (Figure 4), can be oriented in every direction $+30^{\circ}$ and $-30^{\circ}$ from the horizontal. The jet nozzles are designed aerodynamically to provide a very low noise level in high air flow. Thanks to this feature, can be used easily in big and high places like concert halls, theaters, museums where silence is very important. The optimal value of noise for open office areas is in the order of $35 \mathrm{~dB}$. It is possible to catch these values through jet nozzles in the interior where a building is a high-rise and airflow values are high. It reaches the range of $30 \mathrm{~m}$ for the temperature $\left(-30^{\circ} \mathrm{C}, 100^{\circ} \mathrm{C}\right)$ span. Ceiling and wall applications can be done. A sequential or multi-row assembly can be performed. Jet nozzles can be installed with both rectangular duct and circular duct. The nozzle can be directly mounted on duct, or it can be flanged, screwed, riveted with plenum box or flexible connection element. Flexible connections require the opening of a round collar on the channel and a clamping connection. The nozzle is fixed with a hanger system in the flexible connections. In this way, the canal system and the nozzle can be left open without being closed. The nozzle, which is made entirely of aluminum coating process, can be used 
as an electrostatic painted in any color or in most applications as unpainted.

"The most important plumbing system in a building with High Tech application is the heating and ventilation system", Eşsiz stated (Eşsiz,1999). "Instead of a general climate system, today's understanding is to create, in every small independent space, the environmental conditions that anyone using that space can control. In this case, the user will feel most comfortable and be more productive in his work. In general, some climate standards, which are defined without changing local conditions, are implemented with minimal intervention"Eşsiz stated too.But nowadays this norm has been abandoned. Installation and operating costs, interior and facade aesthetics, system maintenance and repair problems have caused the abandonment of independent departmental solutions. The climate control systems that provide local control in the centralized systems (VAV), called variable-flow systems, are nowadays in all modern constructions. These systems, which are compatible with external facade compensation devices that enable automatic control and can be scheduled instantly and seasonally, are more economical in terms of installation and operating costs. Systems with open and/or independent sections that are completely independent and capable of automatic control in each vent have the possibility to operate at the same heating and cooling load. It is suitable for buildings that require very different climatic conditions, like hospitals.

\section{A SAMPLE STUDY: AUTO SHOWROOM}

The architectural structure considered as a case study is a complex consisting of showrooms and offices, sales and service departments serving in the automotive sector in Konya. The device has been selected to arrange inner temperature which is 26 degrees for summer and 22 degrees for winter. R134A or $\mathrm{R} 410 \mathrm{~A}$ refrigerant has used. The electrical system has protected with relays. System designed with automatic drain pump, there has a remote control for each indoor unit and the signaling cable has built under the plaster. Each unit has individually controlled. The plenum boxes has special manufactured according to the measurements in the project. Plenum boxes has insulated with acoustic foam. Flow control damper and connection hangers has manufactured by galvanized sheet. A cooling chiller system with load of $250 \mathrm{~kW}$ the cascade system with heating load of $600 \mathrm{~kW}$ has been used. Sequential jet nozzles have been used in open office plan, showroom and high-rise service areas on ventilation system. Nozzles have been designed in double rows to better accommodate the effect of glass radiation. A homogeneous airflow 
could be provided in this environment. In average nozzle groups, air flow has been provided by the airflow of $750 \mathrm{~m} 3 / \mathrm{h}$.

Unpainted nozzles with metallic appearance has used because of the steel details used in the intermediate partitions, ceiling and duct coverings. It has a modern and aesthetic appearance and they look very harmonious with its surrounds. The steel structure is also the carrier of the duct and piping system to which the nozzles are connected at the same time. Nozzles applied on the indoor front are directed to match the glass facade surrounding the highdense area. In this way, it is possible to provide a homogeneous environment for the summer and winter months at low volume levels in the environment. The automatic drainage system has been used with the same channel structure. Ventilation and air conditioning of closed office environments has also been solved using the same duct system using slot diffusers. Flow controls have been provided with automatic switches and dampers.

Sample building in as shown in (Figure $5 a, 5 b$ ) is a showroom providing service in the automotive sector with a lot of vehicles and human traffic. A lot of cars and trucks are exhibiting in the building. Lots of people and cars activation causes to increase pollutants. There has no time for extensive restoration of the building serving 365 days. For this reason, steel structure roof and partitions have been preferred. Big advantage of the steel structure and nozzles used in the metallic form here is that there is no change in color after the deposition of dust and particles depending on usage over time and no image change around the nozzle. Because of accumulation of impurities on frame, deformation occurs in a short time. Slow flow causes fouling on EU3-EU5 and hepa filters quickly. At the same time, the pressure losses increase while the electricity consumption and noise increases. Time-dependent deformation is not observed on metallic ducts and diffusers.(Figure 6) Prolonged effective ventilation, clean and aesthetic appearance is preserved. Corrosion does not occur, mold and fungus formation is not observed due to proper drainage systems. No repairs or painting is required. Solvent and chemical requirements are reduced. A detailed assesment is shown in Table 1 for diffusers. 

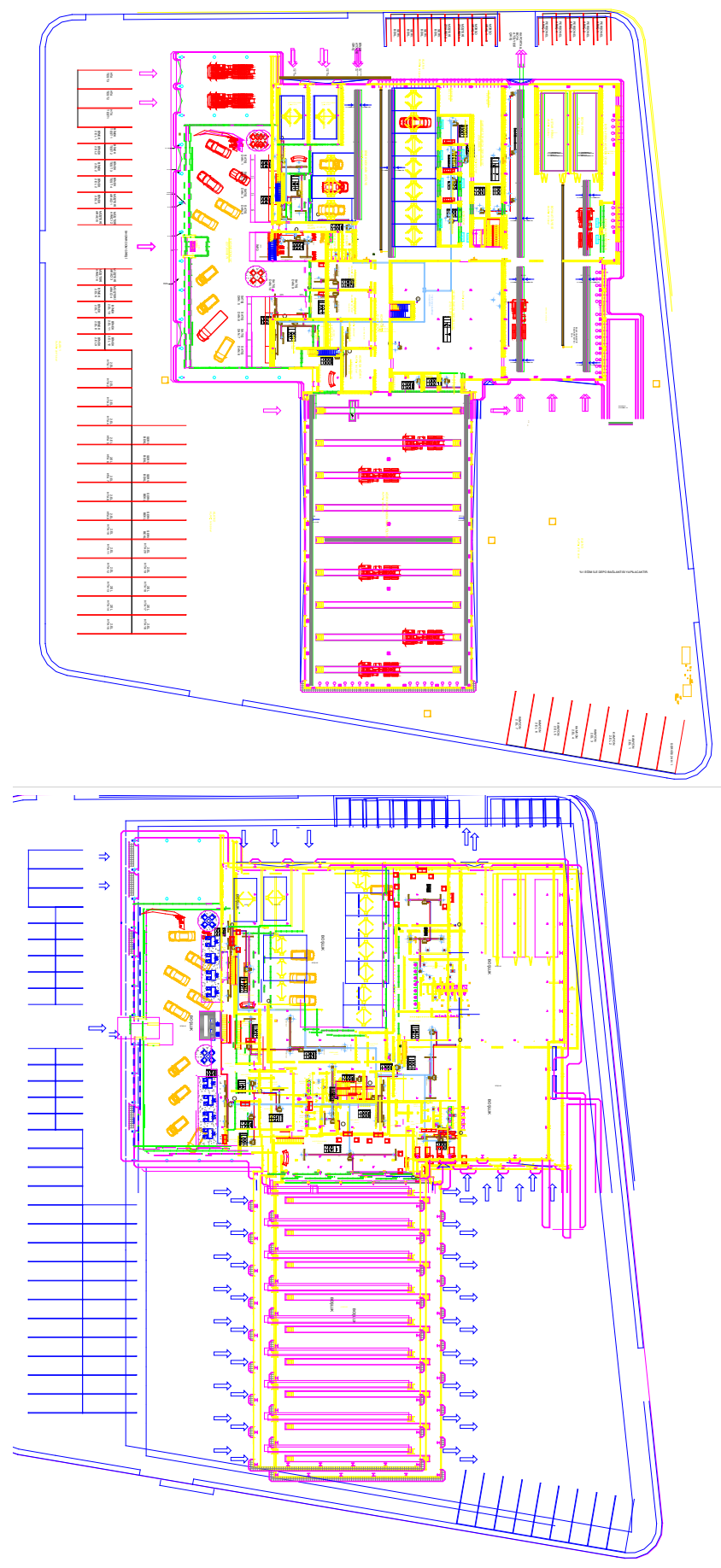

Figure 5a. Showroom and Service 1:Floor Plan

Figure 5b. Showroom and Service 2.Floor Plan 
Figure 6a. and 6b. Showroom and Open-Office Nozzle Groups

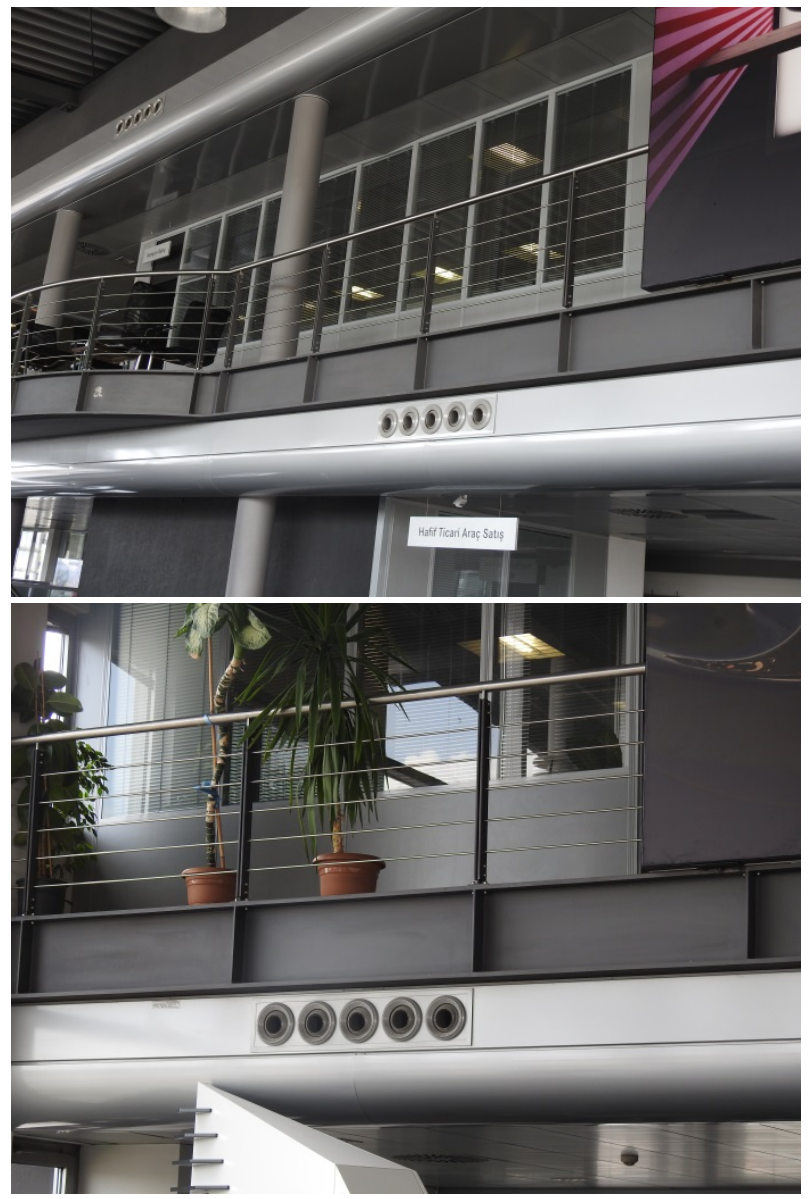

Table 1. Assessment of auto showrooms interior in terms of diffusers criterion

\begin{tabular}{|c|l|}
\hline Criteria & \multicolumn{1}{|c|}{ Modern Diffuser } \\
\hline Color & $\begin{array}{l}\text { Unpainted, metallic appearance, Electrostatic powder } \\
\text { paint (RAL) }\end{array}$ \\
\hline Surface & Modern and aesthetic appearance, \\
\hline Material & $\begin{array}{l}\text { Natural material with low carbon footprint,Cr- } \\
\text { Ni,Aluminium,galvanized steel sheet materials. }\end{array}$ \\
\hline Functionality & $\begin{array}{l}\text { Variable depending on need climate condition, Flexible } \\
\text { production }\end{array}$ \\
\hline Aesthetic & $\begin{array}{l}\text { Variable depending on need, harmonious with its } \\
\text { surroundings environment.A rich appearance with less } \\
\text { varieties of material. }\end{array}$ \\
\hline Plan Type & Modern architecture suitable designs \\
\hline Acustics & $\begin{array}{l}\text { Air flow velocity and acoustics level is convenient for open } \\
\text { plan showroom 35dB }\end{array}$ \\
\hline Sustainability & $\begin{array}{l}\text { Flexible architectural structure with natural material, No } \\
\text { repairs or painting is required, solvent and chemical } \\
\text { requirements are reduced. }\end{array}$ \\
\hline Form & \begin{tabular}{l} 
Environment-form relationship is optimized \\
\hline
\end{tabular} \\
\hline
\end{tabular}




\section{CONCLUSIONS}

Efficiency and sustainability are today's architectural design elements. For this reason, it is very important that the proper ventilation systems are designed, and the system can be used efficiently. In conventional methods, the efficiency of the linear grilles and fan-coil systems used in high-rise structures remains low and the desired air mixing ratios are not achieved in the environment.

Due to the flexible architectural structure, which has dynamic usage areas in modern constructions, it makes possible the necessary transformations over time. The details are very supportive of this dynamism that not hiding in the environment. The most important technical details are not hiding ventilation equipment. Diffuser is extremely important vent equipment, which is also considered in terms of being an architectural identity and decoration object at the same time. Ventilation equipment has made a significant contribution interior design thanks to improved production technologies and material science. It has been observed that the use of these systems in designs modern constructions. New age vent systems have sharp and light manufacturing and they accords with earthquake and fire regulations.

In the past decade, galvanized sheets has been replaced by ducts that are much more aesthetically pleasing, in many forms with circular cross-sections, painted and unpainted in color, and capable of mass production. It has been observed that the ducts made in circular forms have a much better acoustics and thus provide silent and efficient ventilation for summer and winter months at high airspeeds in high-rise structures. The spiro ducts and accessories, which have good sealing and heat transfer properties, are used without being hiding in technological constructions.

With the changing duct forms, the use of the new generation vents has become an inevitable point. It has been observed that the diffusers, which are the extreme points of the installation structure directly affecting the concept of comfort and modernism on the buildings, are the most striking elements of different architectural solutions. New generation distributors with high performance can be shown among the basic elements of industrial style buildings. It is inevitable that the usage of the technical equipment used in these structures increased technological construction style. It is expected that the use of diffusers and ducts like a decorative elements will be spread to the houses and individual space design. Modern diffusers are economical and 
long life using. They look ergonomic compatible with its surroundings. It does not require cleaning frequently. There is no fouling on and around the surface.

Disadvantages of modern diffusers are calculation and design difficulties. Assembly of diffuser must be made precisely. In this for reason, there is a need skilled project and practice team.

There is shown Table 2 effects of diffusers on interior design.

Table 2. Modern diffusers for HVAC Systems

\begin{tabular}{|c|c|c|c|c|c|}
\hline Diffusers & Air Quality & Functions & Aesthetics & Acoustics & Color \\
\hline Anemostat & $\begin{array}{l}\text { The range of } \\
\text { air flow can } \\
\text { be adjusted. }\end{array}$ & $\begin{array}{c}\text { Suitable for } \\
\text { ventilating } \\
\text { ceiling height } \\
\text { not } \\
\text { exceeding } \\
3.5 \text { meters } \\
\text { wc and } \\
\text { similar small } \\
\text { spaces, and } \\
\text { the economic } \\
\text { model. They } \\
\text { are used in } \\
\text { small } \\
\text { ventilation } \\
\text { systems.Max. } \\
300 \mathrm{~m}^{3 / h}\end{array}$ & $\begin{array}{c}\text { It is } \\
\text { generally } \\
\text { used in } \\
\text { hotel,yacht } \\
\text { and hospital } \\
\text { bathrooms. } \\
\text { Diameter is } \\
\text { in the range } \\
\text { of } 100 \mathrm{~mm} \text { - } \\
200 \mathrm{~mm} \text {. }\end{array}$ & $\begin{array}{c}90 \mathrm{~m}^{3} / \mathrm{h} \text { Flow } \\
44 \mathrm{~dB} .\end{array}$ & $\begin{array}{c}\text { Electrostatic } \\
\text { powder } \\
\text { paint (RAL) } \\
\\
\text { Standart } \\
\text { RAL9010 }\end{array}$ \\
\hline Vent & $\begin{array}{l}\text { It can be } \\
\text { produced } \\
\text { with } \\
\text { dampers } \\
\text { The } \\
\text { induction } \\
\text { effect on hot } \\
\text { and cold } \\
\text { flows is } \\
\text { weak. }\end{array}$ & $\begin{array}{c}\text { They are not } \\
\text { preferred in } \\
\text { high } \\
\text { structures. } \\
\text { Suitable for } \\
2,6 \mathrm{~m}-4 \mathrm{~m}\end{array}$ & $\begin{array}{c}\text { Mounted on } \\
\text { wall and } \\
\text { ceiling. } \\
\text { Generally } \\
\text { galvanized } \\
\text { sheet metal } \\
\text { ducts are } \\
\text { mounted } \\
\text { with flexible } \\
\text { straits. Not } \\
\text { suitable for } \\
\text { open channel } \\
\text { applications. }\end{array}$ & $\begin{array}{c}2500 \mathrm{~m} 3 / \mathrm{h} \\
50 \mathrm{~dB} . \\
\text { Avarage } \\
\text { velocity and } \\
\text { flow } 0,2 \mathrm{~m} / \mathrm{s} \text {, } \\
500 \mathrm{~m}^{3} / \mathrm{h} \\
30 \mathrm{~dB} .\end{array}$ & $\begin{array}{l}\text { Standart } \\
\text { RAL9010 It } \\
\text { can be } \\
\text { painted } \\
\text { different } \\
\text { colors }\end{array}$ \\
\hline 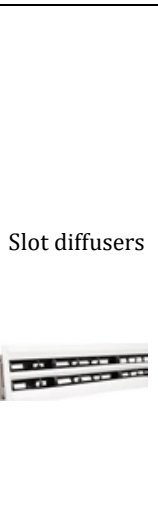 & $\begin{array}{l}\text { Since the } \\
\text { blowing } \\
\text { directions } \\
\text { can vary up } \\
\text { to } 180^{\circ} \text {, they } \\
\text { provide a } \\
\text { homogeneou } \\
\text { s } \\
\text { environment } \\
\text {. }\end{array}$ & $\begin{array}{c}\text { Suitable for } \\
3 \mathrm{~m}-10 \mathrm{~m} \text { In } \\
\text { case of need, } \\
\text { the slot } \\
\text { number can } \\
\text { be increased. }\end{array}$ & $\begin{array}{c}\text { Suitable for } \\
\text { continuous } \\
\text { mounting } \\
\text { and can be } \\
\text { mounted in } \\
\text { parallel rows } \\
\text { to create a } \\
\text { linear image. } \\
\text { Generally, it } \\
\text { is prefered } \\
\text { for hotel, } \\
\text { atrium, mall, } \\
\text { office } \\
\text { modern } \\
\text { interior } \\
\text { design. Easy } \\
\text { and flexible } \\
\text { mounting }\end{array}$ & $\begin{array}{c} \pm 10^{\circ} \text { Temper } \\
\text { ature } \\
\text { difference } \\
\text { and } 2500 \\
\mathrm{~m}^{3} / \mathrm{h} \text { flow } \\
\text { about } 35 \mathrm{~dB} \\
\text { It is } \\
\text { acceptable. }\end{array}$ & $\begin{array}{l}\text { Electrostatic } \\
\text { powder } \\
\text { paint (RAL } \\
\text { Alüminum } \\
\text { anodic } \\
\text { coating }\end{array}$ \\
\hline $\begin{array}{c}\text { Swirl } \\
\text { diffusers }\end{array}$ & $\begin{array}{c}\text { It is } \\
\text { convenient } \\
\text { for heating } \\
\text { and cooling } \\
\text { system. } \\
\text { Effective } \\
\text { ventilation is } \\
\text { possible via } \\
\text { turbulance. }\end{array}$ & $\begin{array}{c}\text { effective use } \\
\text { in the range } \\
\text { of } 2,6 \mathrm{~m}-6 \mathrm{~m} \text {. } \\
\text { It allows } \\
\text { flow setting } \\
\text { and } \\
\text { orientation. }\end{array}$ & $\begin{array}{c}\text { Almost } \\
\text { everywhere } \\
\text { is available, } \\
\text { thanks to its } \\
\text { smooth } \\
\text { design, it is } \\
\text { compatible } \\
\text { with building } \\
\text { decoration. } \\
\text { Not much } \\
\text { prefer for } \\
\text { open ducts } \\
\text { applications }\end{array}$ & $\begin{array}{c}\text { Flow range } \\
200- \\
2500 \mathrm{~m} 3 / \mathrm{h} \\
\max .50 \mathrm{~dB}\end{array}$ & $\begin{array}{c}\text { Electrostatic } \\
\text { powder } \\
\text { paint (RAL) } \\
\text { Metallic } \\
\text { tissue }\end{array}$ \\
\hline
\end{tabular}




\begin{tabular}{|c|c|c|c|c|c|}
\hline $\begin{array}{l}\text { Jet Nozzle } \\
\text { diffusers }\end{array}$ & $\begin{array}{l}\text { It is } \\
\text { convenient } \\
\text { for heating } \\
\text { and cooling } \\
\text { system. } \\
\text { Clean,effectiv } \\
\text { e and silent } \\
\text { ventilating } \\
\text { for high } \\
\text { building. }\end{array}$ & $\begin{array}{c}\text { It can make } \pm \\
30^{\circ} \text { rotation } \\
\text { motion. High } \\
\text { level } 6 \mathrm{~m}- \\
30 \mathrm{~m} \text { can be } \\
\text { used in all } \\
\text { interiors. } \\
\text { Can be used } \\
\text { individually } \\
\text { or as a group } \\
\text { according to } \\
\text { preference } \\
\text { and } \\
\text { preference. }\end{array}$ & $\begin{array}{l}\text { It is applied } \\
\text { to the wall. It } \\
\text { reflects } \\
\text { Machine } \\
\text { aesthetics to } \\
\text { the space. } \\
\text { Any kind of } \\
\text { channel } \\
\text { installation } \\
\text { can be done. } \\
\text { exposed on } \\
\text { the channels } \\
\text { available } \\
\text { appropriate } \\
\text { connection } \\
\text { equipment. }\end{array}$ & $\begin{array}{c}\text { High flow } \\
\text { rates } \\
\left(5000 \mathrm{~m}^{3} / \mathrm{h}\right) . \\
32 \mathrm{~dB} \\
\text { acceptable. }\end{array}$ & $\begin{array}{c}\text { Electrostatic } \\
\text { powder } \\
\text { paint (RAL) } \\
\text { or raw } \\
\text { metallic } \\
\text { surface }\end{array}$ \\
\hline
\end{tabular}

\section{REFERENCES}

Bingelli C. (2003), Building Systems for Interior Designers, John Wiley\&Sons, Hoboken, 194-213, New Jersey, USA.

Int-Hout D. (2004), Best Practices for Selecting Diffusers, Ashrae Journal, pp.24-28.

Eşsiz, Ö. \& Özgen A.(1999) High Tech Mimari,Tasarım+Kuram Dergisi,Cilt 1 ,Sayı 1

Haidong W.,Chen H., Yezan C. \&Xiaofeng J. (2015), Research on a Secondary Air flow-Relay System to Improve Ventilation Performance of Nozzle Supply in Large Space Buildings, Procedia Engineering., 121, pp.816-823.

Haidong W.,Chen H.,Yezan C., \&Yalin Z.,(2018), Experimental study on the characteristics of secondary air flow device in a large enclosed space building, Energy and Buildings, 166, pp.347-357.

LunZ., XiaohuaL., Kang Z.,\&Yi J. (2015), Entransy analysis and application of a novel indoor cooling system in a large space building, International Journal of Heat and Mass Transfer., 85, pp.228-238.

Patrick Sisson How air conditioning shaped modern architecture and changed our climate,

https://www.curbed.com/2017/5/9/15583550/air-conditionin g-architecture-skyscraper-wright-lever-house., 2017, (23.07.2018)

\section{Resume}

Havva Demirpolat was born in Konya 1978. She received the Diploma in Mechanical Engineering from Selçuk University and the Master's degree from Selçuk University. Her Ph.D. degree is from Selçuk University. She is currently working in Selçuk University as aAssist.Professor in Department of Interior Architecture \& Environmental Design. Her research interests include fluid dynamics, CFD, sustainable design. 